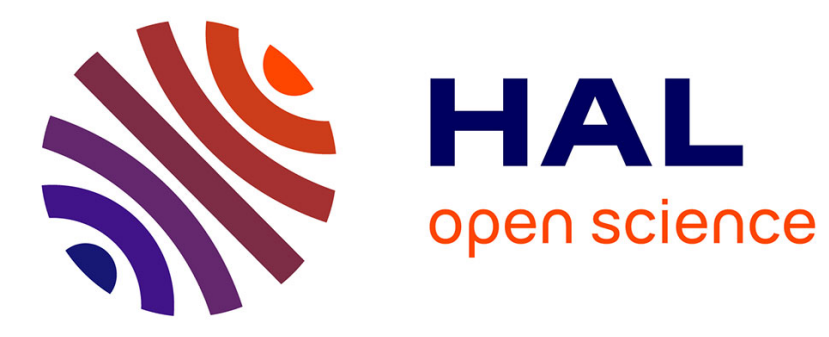

\title{
A Dihydrodinaphthoheptacene
}

Maxime Romain, Cassandre Quinton, Thierry Roisnel, Emmanuel Jacques, Joelle Rault-Berthelot, Cyril Poriel

\section{To cite this version:}

Maxime Romain, Cassandre Quinton, Thierry Roisnel, Emmanuel Jacques, Joelle Rault-Berthelot, et al.. A Dihydrodinaphthoheptacene. Journal of Organic Chemistry, 2018, 83 (4), pp.1891-1897. 10.1021/acs.joc.7b02834 . hal-01739932v2

\section{HAL Id: hal-01739932}

\section{https://hal-univ-rennes1.archives-ouvertes.fr/hal-01739932v2}

Submitted on 14 Sep 2018

HAL is a multi-disciplinary open access archive for the deposit and dissemination of scientific research documents, whether they are published or not. The documents may come from teaching and research institutions in France or abroad, or from public or private research centers.
L'archive ouverte pluridisciplinaire HAL, est destinée au dépôt et à la diffusion de documents scientifiques de niveau recherche, publiés ou non, émanant des établissements d'enseignement et de recherche français ou étrangers, des laboratoires publics ou privés. 


\title{
A Dihydrodinaphthoheptacene
}

Maxime Romain,${ }^{\ddagger}$ Cassandre Quinton, ${ }^{\ddagger}$ Thierry Roisnel, ${ }^{\#}$ Emmanuel Jacques, ${ }^{\dagger}$ Joëlle Rault-Berthelot ${ }^{\ddagger}$ and Cyril Poriel ${ }^{* *}$

+ UMR CNRS 6226-ISCR-Université de Rennes 1-35042 Rennes cedex-France.

\# UMR CNRS 6226-ISCR Centre de Diffractométrie X (CDIFX)- Université de Rennes 1-35042 Rennes cedex-France.

† UMR CNRS 6164, IETR, Université de Rennes 1-35042 Rennes cedex-France.

\begin{abstract}
We report the first example of a dihydrodinaphthoheptacene derivative and the mechanistic investigations of the regioselective electrophilic intramolecular cyclization reaction involved in the synthesis. The structural, electrochemical and photophysical properties have been investigated.
\end{abstract}

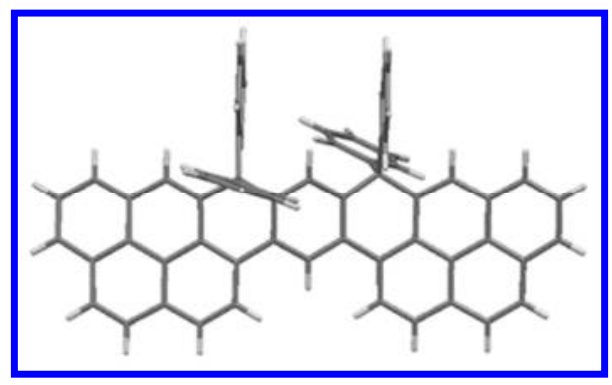

\section{Introduction}

Despite the fantastic advances in the last decade in organic electronics, ${ }^{1,2} 3$ the synthesis of novel highly efficient organic semi-conductors and a better understanding of the relationship between molecular structure and device properties are still the major challenges in the field. In this context, the pyrene fragment has appeared as a promising and versatile building block and novel pyrene based organic materials are strongly desired for such applications (Chart 1). ${ }^{4}$ On the other hand fused or bridged oligophenylenes also have attracted tremendous interest notably due to the exceptional properties of pentacene $^{5-7}$ based materials. Synthesizing such elaborated molecular scaffolds remains nowadays one of the important challenge of organic chemists involved in organic electronics. To reach this goal, it is crucial to perfectly understand from a mechanistic point of view the most important chemical reactions used to synthesise organic semi-conductors. For example, oxidative cyclodehydrogenation reactions have been successfully investigated by Müllen et al showing their potentials to construct extended polycyclic aromatic hydrocarbons based on the pyrene units. ${ }^{8}$ Electrophilic intramolecular cyclization reactions are known for many years as powerful tools to generate spiro carbons ${ }^{9-13,14}$ and more generally quaternary carbon bridgeheads. ${ }^{15}$ These bridgeheads are of key importance in the structure of organic materials to tune their molecular (eg by electronic effects) or supramolecular ( $\mathrm{g}$ by steric effects) properties. However, controlling intramolecular cyclization reactions is far to be an easy task and often leads to numerous positional isomers. ${ }^{16}$ Thus, non-regioselective intramolecular cyclizations have previously been reported for different classes of important organic semi-conductors such as dihydroindenofluorenes ${ }^{16,17}$ and their extended counterparts, ${ }^{18}$ or indolocarbazoles. ${ }^{19,20}$ If this non-regioselectivity can be considered 
as beneficial to obtain many positional isomers with different molecular shapes, it often requires challenging purification steps and regioselective cyclizations are therefore highly desired. As the design of novel molecular fragments is of key importance for the future of electronics, we herein report the first example of a dihydrodinaphthoheptacene derivative (Molecule 6, Chart 1) and the mechanistic investigations of the regioselective intramolecular cyclization reaction involved in its synthesis.
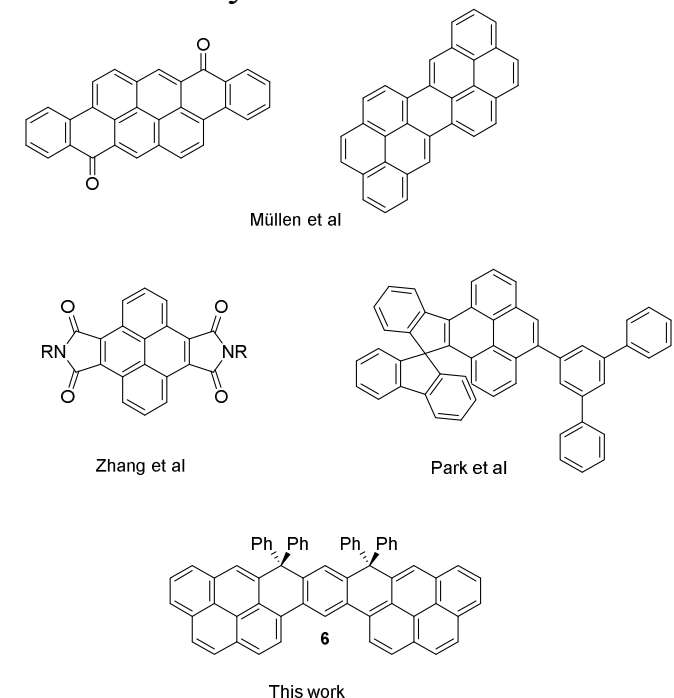

Chart 1: Recently reported fused and bridged pyrene based materials. ${ }^{\text {This work }}{ }^{8,-23}$

\section{Results and Discussion}

The dihydrodinaphthaloheptacenyl fragment is constructed on the assembly of two side pyrenyl units substituted at positions 1 and 10 to a central meta-substituted phenyl ring. The structural, electrochemical and photophysical properties have been investigated in detail as well as a first incorporation in an electronic device. It should be mentioned that pyrene based materials selectively substituted at both positions 1 and 10 are almost absent from literature linked to organic electronics. ${ }^{4,21,22,24,25}$ The present synthesis (Figure 1) is highly efficient and starts with the Suzuki-Miyaura cross coupling of diethyl 4,6dibromoisophthalate $\mathbf{1}^{26}$ with 1-pyreneboronic acid to provide compound $\mathbf{2}$ (86\% yield) with the ethanoate functions on the central ring and in ortho position of each pyrene unit. Diester 2 further reacts with phenyllithium to provide the diol $\mathbf{3}$ (not isolated) and immediately cyclized through an intramolecular electrophilic cyclization $(\mathrm{MsOH}, \mathrm{rt})$ to provide a single product, further assigned to molecule 6 (91\% yield, Figure 1). However, determination of the molecular structure of this final product was not obvious (See NMR studies in SI). Indeed, theoretically, the intramolecular cyclization may occur on different positions of the pyrene ring ( $\mathrm{C} 2$ or $\mathrm{C} 10)$ leading to three possible molecules, 4,5 and $\mathbf{6}$ with either two five membered rings (4), one five membered ring and one six membered ring (5) or two six membered rings (6), Figure 1. As the ester groups of $\mathbf{3}$ are positioned on the central phenyl ring, only a syn configuration can be nevertheless obtained. The interesting regioselectivty of the present intramolecular cyclization may be related to the different nucleophilicity of the pyrene unit ( $\mathrm{C} 2$ vs $\mathrm{C} 10)$. Thus, from a mechanistic point of view, aromatic electrophilic attack from diol $\mathbf{3}$ affords the corresponding Wheland-type intermediate ${ }^{27}$ that eventually leads to the respective $\mathbf{4 , 5}$ and $\mathbf{6}$ positional isomers upon fast deprotonation. We assume herein that this reaction sequentially occurs (Figure 1). In order to study the different nucleophilic centres in term of reactivity and to shed light on the regioselectivity of the reaction, theoretical calculations have been performed on the reaction intermediates (I1-3, Figure 1), which are the carbocations obtained in acidic media. Thus, the frontier orbitals HOMO and LUMO of 
the reaction intermediates I1-3 and their overlap may provide key information on the $\mathrm{C} 2$ and $\mathrm{C} 10$ reactivity. Considering two sequential aromatic electrophilic substitutions, we have first been interested in the monocarbocation intermediate I1 (See structure in Figure 1). As expected, the LUMO of I1 is spread out on the carbocation $\left(-\mathrm{C}^{+}-(\mathrm{Ph})_{2}\right)$, (Figure 2, Top-left), which is the electrophilic centre. Since the HOMO of I1 is spread on the pyrene fragment (Figure 2, Bottom-left), which is located at the opposite of the carbocation, an overlap between the HOMO and the LUMO to give a new C-C bond is impossible. For this reason, the HOMO-1 has also been considered (HOMO and HOMO-1 are indeed very close in energy: $-7.17 \mathrm{eV}$ and $-7.46 \mathrm{eV}$ resp.) and appears to be localized on the other pyrene unit, close to the carbocation.

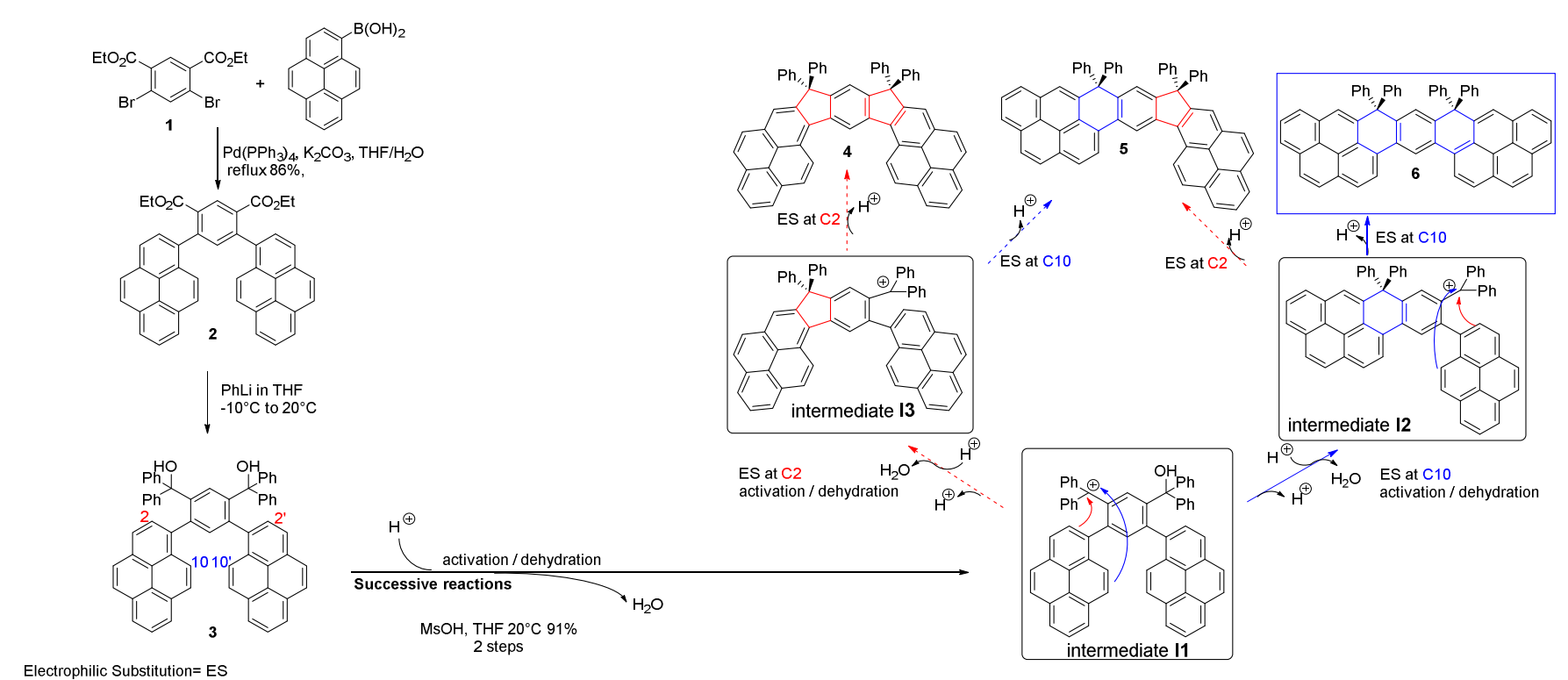

Figure 1. Considered pathways from non-isolated compound 3 to final compounds 4,5 and 6

More importantly, each pyrene unit possesses two nodal planes: the first in the plane of the pyrene core and the second along the $\mathrm{C} 2-\mathrm{C} 7$ axis being orthogonal to the plane of the pyrene core. Due to these nodal planes, the molecular orbital coefficient at $\mathrm{C} 2$ is null and there is no possible overlap between the LUMO and the HOMO/HOMO-1 at this position. The resulting five membered ring can hence not be formed. In addition, the coefficient on the $\mathrm{C} 10$ atom is important and hence an overlap between LUMO and HOMO-1 at this position can occur resulting to the formation of a six membered ring. Thus, the first cyclization appears to regioselectively occur at $\mathrm{C} 10$ with no contribution of $\mathrm{C} 2$ and should provide after activation and dehydration the reaction intermediate $\mathbf{I} 2$ possessing a bridged six membered ring, whereas the reaction intermediate $\mathbf{I} \mathbf{3}$ cannot be obtained and will hence not be further considered.

As above mentioned for $\mathbf{I 1}, \mathrm{HOMO}$ of $\mathbf{I} \mathbf{2}$ is also spread out on the pendant pyrene fragment with an important coefficient on the $\mathrm{C} 10$ atom and no contribution on the $\mathrm{C} 2$ atom (Figure 2, Bottom-right). As the LUMO (Figure 2, Top-right) is still located on the carbocation $\left.\left(-\mathrm{C}^{+}-(\mathrm{Ph})_{2}\right)\right)$, the overlap between the LUMO and the HOMO favours the formation of a $\mathrm{C}-\mathrm{C}$ bond between the carbocation and $\mathrm{C} 10$ and a second six membered ring is formed leading to the final compound, namely the dihydrodinaphthoheptacene $\mathbf{6}$. In the light of these theoretical investigations, it clearly appears that $\mathbf{6}$ is the only possible compound which can be obtained in this peculiar regioselective reaction. It is important to note that such regioselectivity was for example not observed in the case of dihydroindenofluorene positional isomers ${ }^{16}$ (a structurally related family of bridged oligophenylenes for electronics) and may be an efficient tool to regioselectively synthesize other dihydrodinaphthoheptacenes or more generally pyrene based materials substituted at $\mathrm{C} 1$ and $\mathrm{C} 10$. 


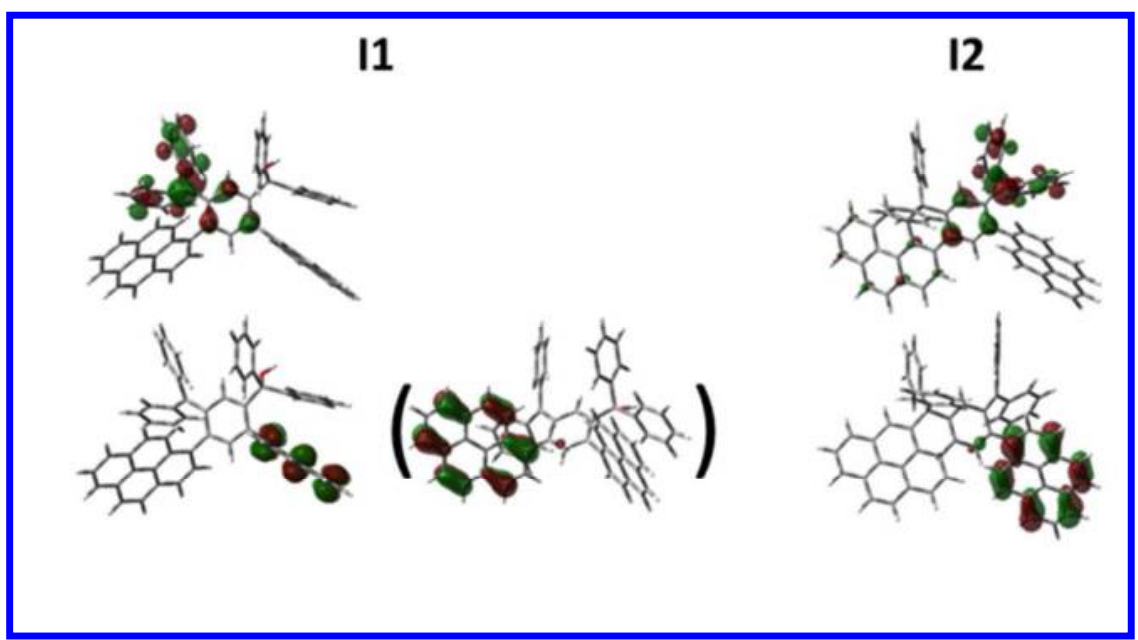

Figure 2. Representation of LUMO (top) and HOMO (bottom) of the intermediates I1 (left, HOMO-1 is also presented in brackets), I2 (right) obtained by DFT B3LYP/6-31g(d) isovalue of 0.04 [e bohr $\left.{ }^{-3}\right]^{1 / 2}$.

The molecular structure of $\mathbf{6}$ has been confirmed by X-ray diffraction on single crystals obtained by slow evaporation of a $\mathrm{CD}_{2} \mathrm{Cl}_{2}$ solution (Figure 3 ). The dihydrodinaphthoheptacenyl core of 6 has a maximum length of $17.2 \AA$ and displays a surprising $Z$ shape with a strong deviation from planarity. Indeed, the angles between the plane of the pyrene units and that of the central phenyl ring are as high as $21.9^{\circ}$ and $11.9^{\circ}$. This feature is surely caused by the central meta substituted phenyl ring, which not only restricts the delocalization of $\pi$-electrons ${ }^{28}$ (see below) but also induces peculiar structural characteristics. We also note that each six membered ring substituted at the bridgehead by the two pendant phenyl rings is strongly distorted with a deviation from planarity of $33^{\circ}$ and $24.4^{\circ}$, see SI. The packing of $\mathbf{6}$ displays a nice dimer arrangement, clearly highlighting short intermolecular distances $\left(\mathrm{d}_{\mathrm{C} / \mathrm{C}}=3.29 \AA\right)$ between pyrene units being significantly shorter than the sum of their van der Waals radii $(3.40 \AA)$. These short contacts will have important repercussions on the electronic properties at the solid state.

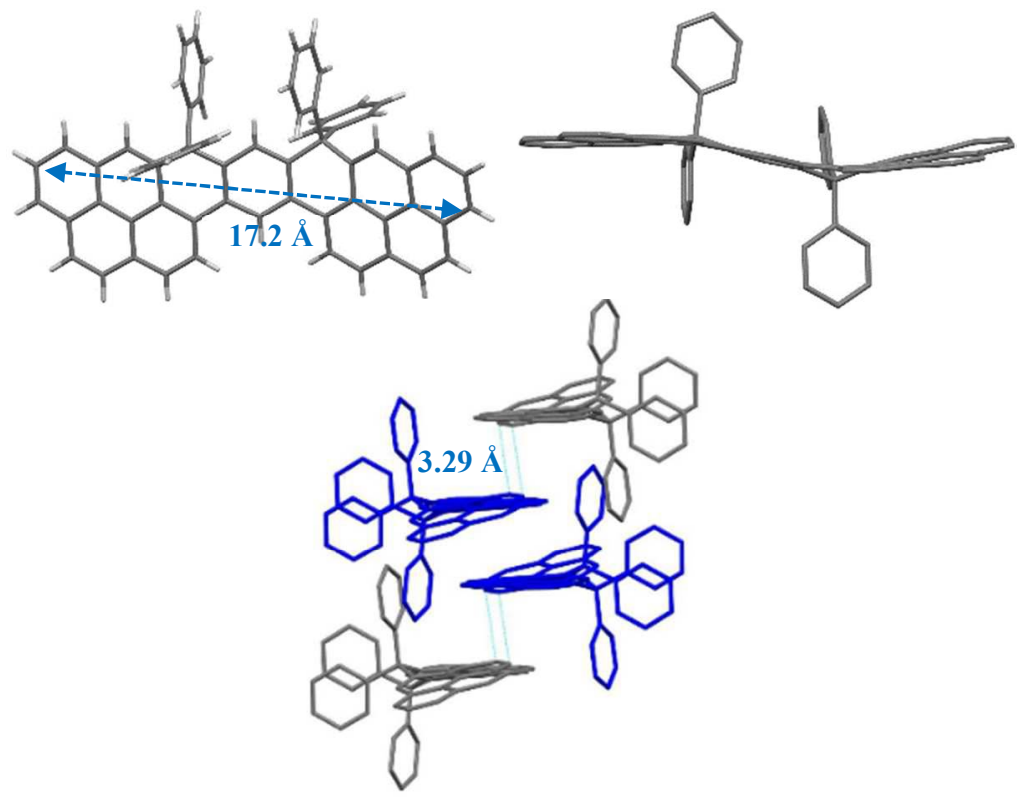

Figure 3: Molecular structures from X-Ray crystallography of 6 (Top, left: face view, right: side view, Bottom: diagram packing) 
The cyclic voltammetry (CV) of $\mathbf{6}$ shows two successive reversible oxidation waves, with maxima recorded at 1.11 and $1.29 \mathrm{~V} v s$ SCE (Figure 4, Top-left) followed by an irreversible oxidation wave with a maximum around $1.9 \mathrm{~V}$.

In the light of the electronic distribution of the HOMO and and the spin density of the radical cation (using Density Functional Theory (DFT) at the Gaussian09 B3LYP/6-31g(d) level of theory, see SI), the two first monoelectronic oxidation wave have been assigned to the formation of two radical cations delocalized each on the half molecule that means each on a five-ringed benzopyrene core (olympicene isomer ${ }^{29}$ ). This feature is caused by the meta linkages between the central phenyl ring and the side pyrenyl fragments, which efficiently disrupt the $\pi$-conjugation (see below). The reversibility of these two first waves indicates that the bis-radical-cations are highly stable at the CV time scale. In reduction, two ill-defined waves are detected with peak potentials recorded at $-2.00 \mathrm{~V}$ and $2.25 \mathrm{~V}$ (see SI). In the light of the electron density of the LUMO and the spin density of the radical anion (see SI), the two successive reductions are assigned to the formation of two benzopyrene radical-anions. It is important to mention that reduction waves are rarely observed for pure hydrocarbon derivatives with extended $\pi$-conjugated cores and are often only detected as a threshold at very low potential, close to the electrolyte discharge. ${ }^{30}$ The HOMO/LUMO energy levels ${ }^{31}$ have been determined at $-5.39 \mathrm{eV}$ and $-2.51 \mathrm{eV}$ respectively (from the onset of the oxidation/reduction waves), ${ }^{31}$ providing a short electrochemical gap $\Delta \mathrm{E}_{\mathrm{El}}$ of $2.88 \mathrm{eV}$. Several important features need to be further stressed. First, an inspection of the shape of the HOMO/LUMO distribution of $\mathbf{6}$ reveals that there is a $\pi$-conjugation interruption at the two opposite carbon atoms of the central phenyl ring (nodal plane). As above mentioned, the meta linkages are the cause of this nodal plane, which disrupt the electronic coupling between the central phenyl ring and the side pyrenyl fragments. A similar feature has been recently observed for a structurally analogue dihydro[2,1-b]indenofluorene backbone.$^{17}$ Thus, the HOMO energy level is maintained at a relatively low energy level $(-5.39 \mathrm{eV})$ for such extended $\pi$-conjugated molecule composed of two benzopyrenyl fragments. For comparison purpose, electrochemistry of constituting building block pyrene has also been performed in similar conditions $\left(\mathrm{Bu}_{4} \mathrm{NPF}_{6} 0.2 \mathrm{M}\right.$ in $\mathrm{CH}_{2} \mathrm{Cl}_{2}$, see $\left.\mathrm{SI}\right)$ leading to lower/higher HOMO/LUMO energy levels of $-5.54 \mathrm{eV} /-2.32 \mathrm{eV}$ respectively $\left(\Delta \mathrm{E}_{\mathrm{El}}=3.22 \mathrm{eV}\right)$. Interestingly and from an HOMO/LUMO point of view, $\mathbf{6}$ also bears a strong resemblance to the tetracene molecule (Benz[b]anthracene) constituted of four fused phenyl rings $(-5.4 \mathrm{eV} /-2.4 \mathrm{eV}){ }^{32}$

Iterative cycles in the potential range involving only the two first oxidation waves do not show any modification of the $\mathrm{CV}$ nor of the electrode surface confirming the stability of the charges in the CV timescale. However, when scanning in a larger potential range, ie between 0.25 and $2.15 \mathrm{~V}$ (10 successive cycles, Figure 4, Top-right) and hence including the third oxidation wave, the current gradually increases with the appearance of a new wave at a low potential (between $0.79 \mathrm{~V}$ for cycle 1 to $0.92 \mathrm{~V}$ for cycle 10) and a gradual shift of the onset potential to lower potentials. This feature can be assigned to the oxidation of the benzo-pyrene units of $\mathbf{6}$ with immediate coupling between the generated benzo-pyrene radical-cations and precipitation of an insoluble electroactive deposit on the electrode. ${ }^{33}$ 

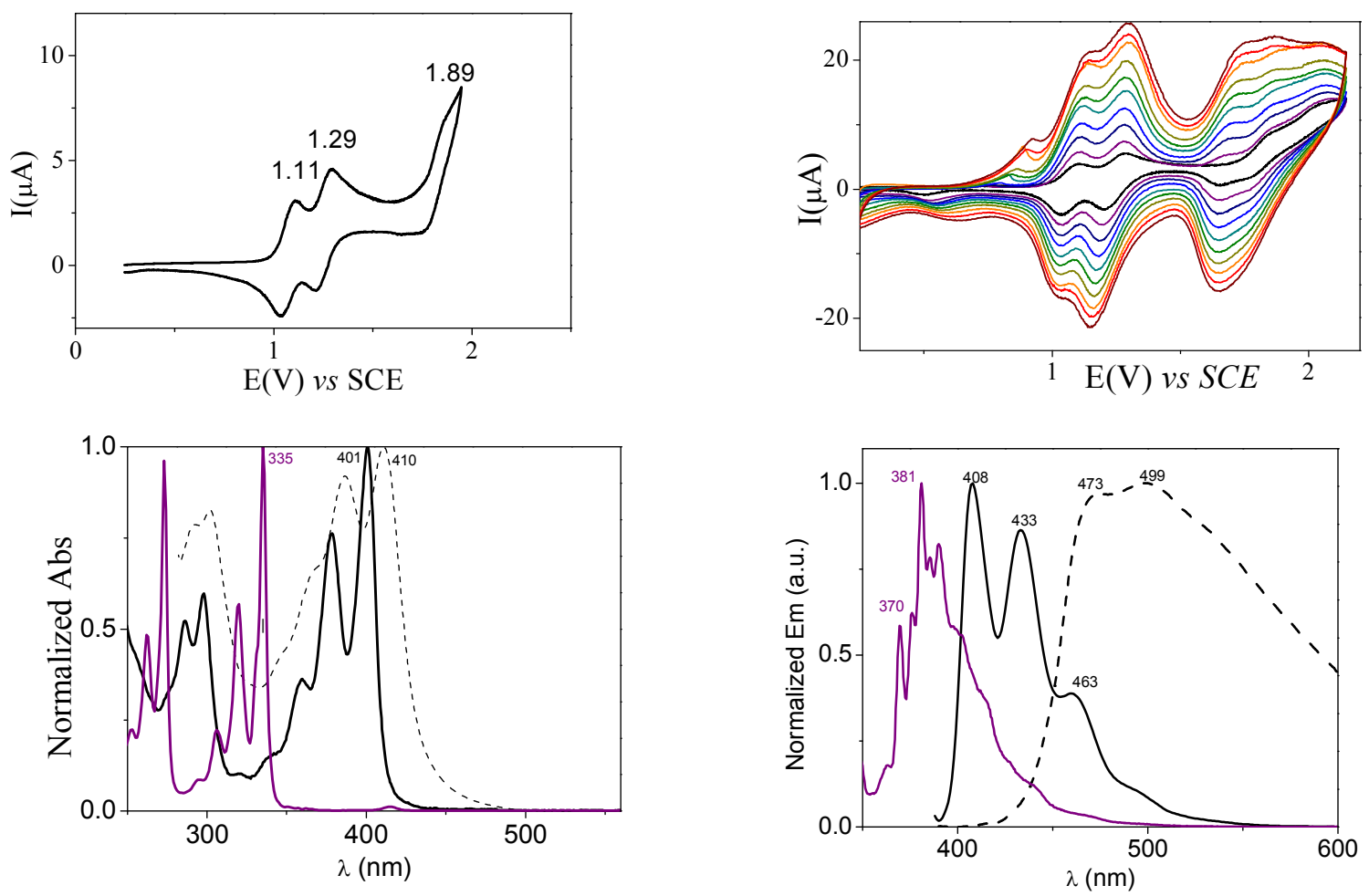

Figure 4: Top: $\mathrm{CV}$ at $100 \mathrm{mV} / \mathrm{s}$ of $6\left(2 \times 10^{-3} \mathrm{M}\right)$ in $\mathrm{CH}_{2} \mathrm{Cl}_{2} /\left[\mathrm{Bu}_{4} \mathrm{~N}\right]\left[\mathrm{PF}_{6}\right] 0.2 \mathrm{M}$. 1 scan, $0.25-1.95 \mathrm{~V}$ (Left), 10 scans $0.25-2.15 \mathrm{~V}$ (Right). Bottom: Absorption spectra of pyrene (purple) and 6 (black) in cyclohexane and as thin solid film (dash), Emission spectra of pyrene (purple, $\lambda_{\text {exc }}=317 \mathrm{~nm}$ ) and of 6 (black, $\lambda_{\text {exc }}=378 \mathrm{~nm}$ ) in cyclohexane and as thin solid film (dash, $\lambda_{\mathrm{exc}}=370 \mathrm{~nm}$ ).

The gradual decrease in the oxidation onset potential during the process can be directly linked to the extension of the $\pi$-conjugated core favouring the electron delocalization. This feature has already been observed for other bridged oligophenylenes ${ }^{34}$ and is further supported by the study of the resulting deposit in an electrolytic solution free of monomer $\mathbf{6}$ (see SI). Thus, the resulting insoluble deposit clearly displays two reversible waves with maxima at 0.78 and $1.22 \mathrm{~V}$, leading to a very high HOMO energy level lying at $-4.9 \mathrm{eV}$. There is hence a strong increase of the deposit HOMO level compared to that of the monomer $\mathbf{6}$, clearly confirming an increase of the $\pi$-conjugation pathway in the former. However, the determination of the carbon-carbon coupling position remains difficult to assign. Indeed, it is widely known that electrophilic substitution of pyrene usually occurs at positions 1, 3, 6 and $8^{4}$ and similarly, the electropolymerization also occurs through deprotonation of these positions. ${ }^{33}$ In the case of $\mathbf{6}$, it is nevertheless difficult to assign with a complete certitude, the positions involved in the anodic polymerization. Indeed, if the position 1 (on the same side of the phenyl bridges) seems to be too sterically hindered to allow polymerization, the latter may occur either at the positions 3 and 6 of the pyrene units (see examples in SI).

UV-Vis absorption and fluorescence spectra of $\mathbf{6}$ are presented Figure 4, Bottom. In cyclohexane, $\mathbf{6}$ presents a structured absorption spectrum (as observed for pyrene) with five thin bands at 286, 298, 360,379 and $401 \mathrm{~nm}$ with very high molar absorption coefficients $\left(\varepsilon_{286 \mathrm{~nm}}=5.2 \times 10^{4}, \varepsilon_{298 \mathrm{~nm}}=5.2 \times 10^{4}\right.$, 
$\varepsilon_{360 \mathrm{~nm}}=3.6 \times 10^{4}, \varepsilon_{379 \mathrm{~nm}}=7.6 \times 10^{4}, \varepsilon_{401 \mathrm{~nm}}=9.9 \times 10^{4} \mathrm{~L}_{\mathrm{mol}} \mathrm{m}^{-1} \mathrm{~cm}^{-1}$ ), translating an efficient chromophore. The absorption maximum is close to that reported for a naphtotetracene, which can be considered as a half of $6 .{ }^{35}$ This confirms the disruption of the $\pi$-conjugation induced by the meta linkages.

Time Dependant DFT (TD-DFT) calculations (Figure 5) reveal that the lowest calculated energy transitions of $\mathbf{6}$, corresponding to a HOMO/LUMO transition located on the dihydronaphthoheptacenyl core has an oscillator strength of 0 . This value appears in a first attempt surprising as the $\mathrm{HOMO} / \mathrm{LUMO}$ transitions are usually very intense in such pure hydrocarbon $\pi$-conjugated molecule. However, in the present case, the HOMO/LUMO transition seems to be forbidden due to symmetrical considerations. Thus, the two main experimental absorption bands of 6 (401 nm and $397 \mathrm{~nm})$ are due to a transition possessing two contributions HOMO-1/LUMO and $\mathrm{HOMO} / \mathrm{LUMO}+1$ with a vibrational structure. In emission spectroscopy (Figure 4, Bottom-right), 6 displays a well resolved spectra, mirror image of its absorption with two main bands at 408 and 433 $\mathrm{nm}$ with a quantum yield estimated at ca $65 \%$. We can note that this quantum yield is twice that of pyrene (32\%), translating an efficient blue fluorophore. Thus, $\mathbf{6}$ displays both absorption and emission red shifted compared to pyrene $\left(\lambda_{\text {abs }}=335 \mathrm{~nm} / \lambda_{\text {em }}=370 \mathrm{~nm}\right)$.

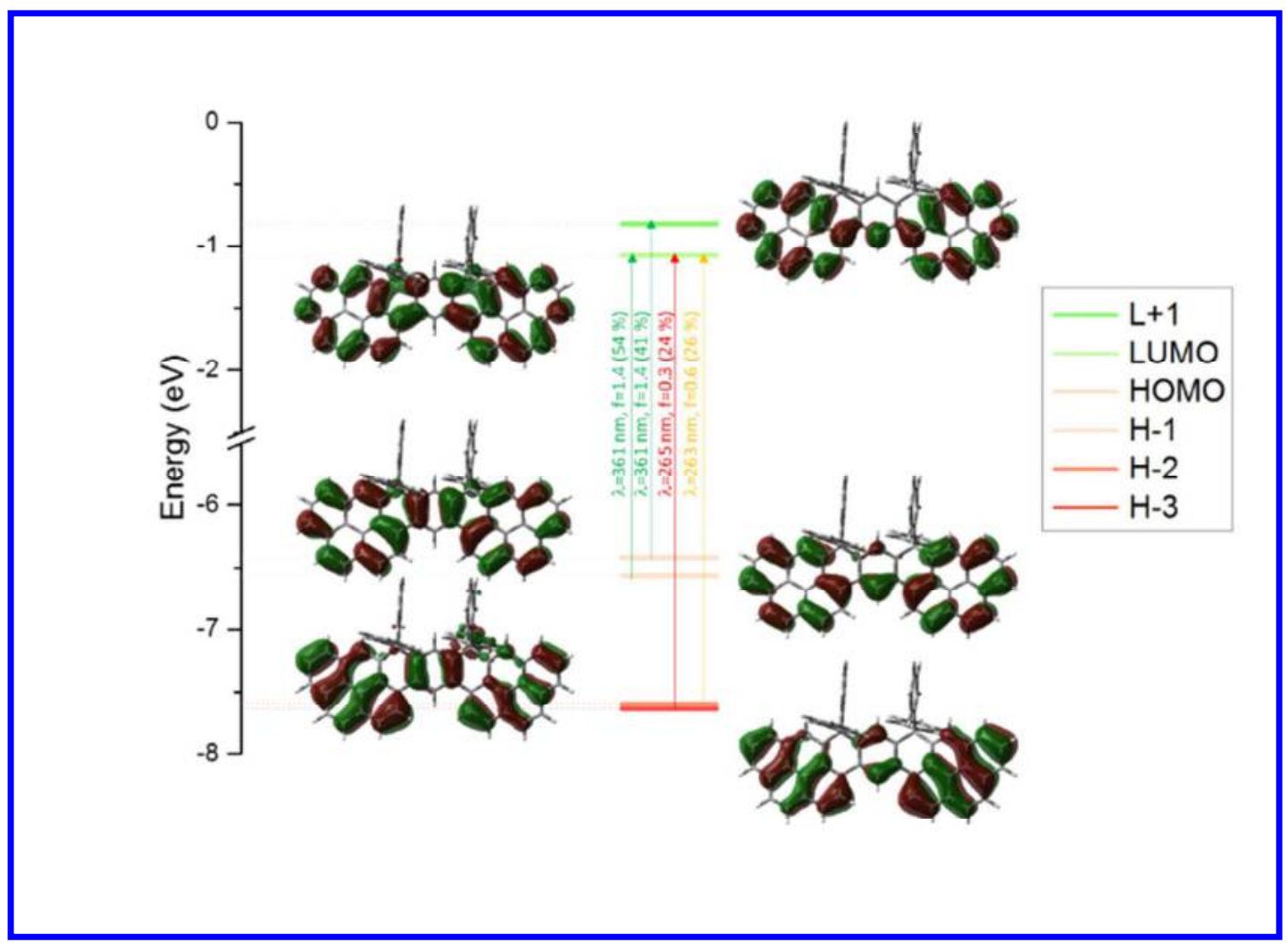

Figure 5. Representation of the energy levels and the main orbitals involved in the electronic transitions of 6 obtained by TD-DFT CAM-B3LYP/6-311G(d,p), shown with an isovalue of $0.02\left[\mathrm{e} \mathrm{bohr}^{-3}\right]^{-}$ ${ }^{1 / 2}$. For clarity purpose, only the main contribution of each transition is shown for the high energy transitions.

The fluorescence spectrum of $\mathbf{6}$ in the solid state is larger and red-shifted compared to that in solution (shift of the $\lambda_{\max }$ from $408 / 433 \mathrm{~nm}$ in solution to $473 / 499 \mathrm{~nm}$ in the solid state) (Figure 4, bottom-right). This feature translates the tendency of the dihydrodinaphthoheptacenyl fragment to stack in the solid state as highlighted in the packing diagram exposed below. This feature is somewhat surprising as most of the time when a molecule is substituted on the bridgeheads with bulky units, the stacking is strongly limited. ${ }^{36}$ However, in the present case, the extended dinaphthoheptacene 
cores allows intermolecular interactions to occur. Measuring the hole mobility of $\mathbf{6}$ through the SCLC technique confirms this feature (see device structure in SI). Indeed, 6 displays a hole mobility of $1.8 \times 10^{-4} \mathrm{~cm}^{2} /$ V.s, more than 10 times higher than that of the Dispirofluorene-Indeno[2,1b]fluorene analogue possessing the same central meta-terphenyl linkage (see structure in $\mathrm{SI}), 1.4 \times 10^{-5} \mathrm{~cm}^{2} / \mathrm{V}$.s. This slight mobility increase can be assigned to the incorporation of the side pyrenyl unit which favours the intermolecular interactions. To conclude, we report in this work the regioselective synthesis and the electronic properties of an unprecedented dihydrodinaphthoheptacene derivative. Thanks to a detailed mechanistic study, the origin of the regioselectivity has notably been unravelled and appears as an efficient tool to synthesize 1,10-disubstituted pyrenes. Given the importance of this type of cyclization reaction and of extended planarized PAHs in organic electronics, the present finding may be used to direct and control the synthesis of other extended semiconductors.

\section{Experimental Section}

\section{General Experimental methods}

Synthesis: Commercially available reagents and solvents were used without further purification other than those detailed below. THF was distilled from sodium/benzophenone prior to use. Light petroleum refers to the fraction with $b p 40-60^{\circ} \mathrm{C}$. Reactions were stirred magnetically, unless otherwise indicated. Analytical thin layer chromatography was carried out using aluminum backed plates coated with Merck Kieselgel 60 GF254 and visualized under UV light (at 254 and $360 \mathrm{~nm}$ ). Chromatography was carried out using Teledyne Isco CombiFlash ${ }^{\circledR}$ Rf 400 (UV detection 200-360nm), over standard silica cartridges (Redisep ${ }^{\circledR}$ Isco standard $(40-60 \mu)$ or Gold $\left.(20-40 \mu)\right)$. ${ }^{1} \mathrm{H}$ and ${ }^{13} \mathrm{C}$ NMR spectra were recorded using Bruker $300 \mathrm{MHz}$ instruments $\left({ }^{1} \mathrm{H}\right.$ frequency, corresponding ${ }^{13} \mathrm{C}$ frequency: $\left.75 \mathrm{MHz}\right)$; chemical shifts were recorded in ppm and J values in $\mathrm{Hz}$. In the ${ }^{13} \mathrm{C}$ NMR spectra, signals corresponding to $\mathrm{CH}, \mathrm{CH}_{2}$ or Me groups, assigned from DEPT, are noted; all others are $\mathrm{C}$. The residual signal for the $\mathrm{CD}_{2} \mathrm{Cl}_{2}$ is $5.32 \mathrm{ppm}$ for the proton and $54.00 \mathrm{ppm}$ for the carbon. The following abbreviations have been used for the NMR assignment: $\mathrm{s}$ for singlet, $\mathrm{d}$ for doublet, $\mathrm{t}$ for triplet and $\mathrm{m}$ for multiplet. High resolution mass spectra were recorded at the Centre Régional de Mesures Physiques de l'Ouest (Rennes) on (i) Bruker MicrO-Tof-Q II (Source: Atmospheric Pressure Chemical Ionisation (APCI - direct introduction (ASAP-Atmospheric Solids Analysis Probe) at a temperature of $30^{\circ} \mathrm{C}$ - positive mode) or on (ii) Waters Q-Tof II (source: electrospray (ESI)). Diethyl 4,6-dibromoisophthalate was synthesized as previously reported. $^{26}$

X Ray: $\left(\mathrm{C}_{64} \mathrm{H}_{38}, \mathrm{C} \mathrm{H}_{2} \mathrm{Cl}_{2}\right) ; M=891.87$. APEXII, Bruker-AXS diffractometer, Mo-K $\alpha$ radiation $(\lambda=0.71073 \AA), T=150(2) \mathrm{K}$; monoclinic $P 2{ }_{1} / n$ (I.T.\#14), a = 12.5987(8), $\mathrm{b}=16.8102(13), \mathrm{c}=$

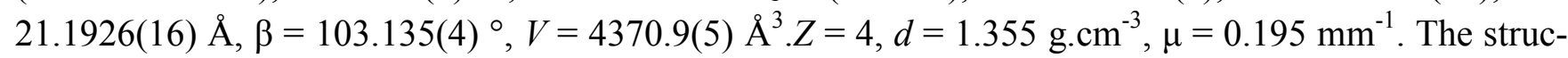
ture was solved by direct methods using the SIR97 program ${ }^{37}$, and then refined with full-matrix leastsquare methods based on $\mathrm{F}^{2}$ (SHELXL-97) ${ }^{38}$ with the aid of the WINGX ${ }^{39}$ program. All non-hydrogen atoms were refined with anisotropic atomic displacement parameters. $\mathrm{H}$ atoms were finally included in their calculated positions. A final refinement on $F^{2}$ with 9862 unique intensities and 604 parameters converged at $\omega R\left(F^{2}\right)=0.1591(R(F)=0.071)$ for 4079 observed reflections with $I>2 \sigma(I)$.

Spectroscopic studies: Cyclohexane (AnalaR NORMAPUR, VWR), Toluene (Spectrometric grade 99,7\%, Alfa Aesar), Chloroform (AnalaR, NORMAPUR, VWR), Ethyl Acetate (for analysis, Carlo Erba), Acetonitrile (Anhydrous for analysis, Carlo Erba), 2-Methylpentane (99+\%, Alfa Aesar), Methylcyclohexane ( $>99.0 \%, \mathrm{TCI}), \mathrm{H}_{2} \mathrm{SO}_{4} 1 \mathrm{~N}$ solution in water (Standard solution, Alfa Aesar), and Quinine sulfate dihydrate (99+\%, Alfa Aesar) were used without further purification. UV-visible spectra 
were recorded using a UV-Visible spectrophotometer SHIMADZU UV-1605. The optical gap was calculated from the absorption edge of the UV-vis absorption spectrum using the formula $\Delta \mathrm{E}^{\mathrm{opt}}(\mathrm{eV})=$ $\mathrm{hc} / \lambda, \lambda$ being the absorption edge (in meter). With $\mathrm{h}=6.63 \times 10^{-34} \mathrm{~J} . \mathrm{s}\left(1 \mathrm{eV}=1.6 \times 10^{-19} \mathrm{~J}\right)$ and $\mathrm{c}=$ $3.0 \times 10^{8} \mathrm{~m} . \mathrm{s}^{-1}$, this equation may be simplified as: $\Delta \mathrm{E}^{\mathrm{opt}}(\mathrm{eV})=1237.5 / \lambda$ (in $\left.\mathrm{nm}\right)$. Photoluminescence spectra were recorded with a PTI spectrofluorimeter (PTI-814 PDS, MD 5020, LPS 220B) using a xenon lamp. Quantum yields in solution $\left(\varnothing_{\mathrm{sol}}\right)$ were calculated relative to quinine sulfate $\left(\varnothing_{\mathrm{sol}}=0.546\right.$ in $\left.\mathrm{H}_{2} \mathrm{SO}_{4} 1 \mathrm{~N}\right) . \emptyset_{\text {sol }}$ was determined according to the following equation (1),

$$
\phi_{s o}=\phi_{r e f} \times 100 \times \frac{(T s \times A r)}{(T r \times A s)}\left[\frac{n_{s}}{n_{r}}\right]^{2}
$$

where, subscripts s and $r$ refer respectively to the sample and reference. The integrated area of the emission peak in arbitrary units is given as $\mathrm{T}, \mathrm{n}$ is the refracting index of the solvent $\left(\mathrm{n}_{\mathrm{s}}=1.427\right.$ for Cyclohexane) and $\mathrm{A}$ is the absorbance. 4 solutions of different concentration of the substrate $(\mathrm{A}<0.1)$ were prepared and 4 solutions of quinine sulfate, and absorption and emission spectrum were recorded (excitation at $336 \mathrm{~nm}$ for the quinine sulfate). Slope of the integrated emission intensity vs absorbance gave Tx/Ax. 4 quantum yields are then calculated and the average value is reported. IR spectra were recorded on a Bruker Vertex 70 using a diamond crystal MIRacle ATR (Pike).

Electrochemical studies: All electrochemical experiments were performed under an argon atmosphere, using a Pt disk electrode (diameter $1 \mathrm{~mm}$ ), the counter electrode was a vitreous carbon rod and the reference electrode was a silver wire in a $0.1 \mathrm{M} \mathrm{AgNO}_{3}$ solution in $\mathrm{CH}_{3} \mathrm{CN}$. Ferrocene was added to the electrolyte solution at the end of a series of experiments. The ferrocene/ferrocenium $\left(\mathrm{Fc} / \mathrm{Fc}^{+}\right)$ couple served as internal standard. The three electrode cell was connected to a PAR Model 273 potentiostat/galvanostat (PAR, EG\&G, USA) monitored with the ECHEM Software. Activated $\mathrm{Al}_{2} \mathrm{O}_{3}$ was added in the electrolytic solution to remove excess moisture. For a further comparison of the electrochemical and optical properties, all potentials are referred to the SCE electrode that was calibrated at $0.405 \mathrm{~V}$ vs. $\mathrm{Fc} / \mathrm{Fc}^{+}$system. Following the work of Jenekhe, ${ }^{31}$ we estimated the electron affinity (EA) or lowest unoccupied molecular orbital (LUMO) and the ionization potential (IP) or highest occupied molecular orbital (HOMO) from the redox data. The LUMO level was calculated from: $L U M O(e V)=-\left[E_{\text {onset }}^{\text {red }}\right.$ (vs $\mathrm{SCE})+4.4]$ and the HOMO level from: HOMO $(\mathrm{eV})=-\left[\mathrm{E}_{\text {onset }}{ }^{\mathrm{ox}}(\mathrm{vs} \mathrm{SCE})+4.4\right]$, based on an SCE energy level of $4.4 \mathrm{eV}$ relative to the vacuum. The electrochemical gap was calculated from : $\Delta \mathrm{E}^{\mathrm{el}}$ $=|\mathrm{HOMO}-\mathrm{LUMO}|$ (in eV). ${ }^{31,40}$

Theoretical modeling: This work was granted access to the high performance computing resources of CINES (Montpellier, France) under the allocation 2017-A0020805032 awarded by GENCI. Full geometry optimization of the ground state (S0) and frequency calculation were performed with Density Functional Theory (DFT) with the hybrid Becke-3 parameter exchange ${ }^{41-43}$ functional and the Lee-Yang-Parr non-local correlation functional ${ }^{44}$ (B3LYP) implemented in the Gaussian 09 (Revision B.01) program suite ${ }^{45}$ using the $6-31 \mathrm{G}(\mathrm{d})$ basis set and the default convergence criterion implemented in the program. Transition diagrams were obtained through TD-DFT calculations performed using the CAM-B3LYP functionals and the $6-311 \mathrm{G}(\mathrm{d}, \mathrm{p})$ basis set on the geometry of S0. Figures were generated with Gauss View 5.0 and GaussSum 3.0.

Devices. Hole carrier mobility has been estimated using vertical structure with gold electrodes ( $\mathrm{Au} / \mathrm{OSC} / \mathrm{Au}$ with OSC thickness of ca $\sim 40 \mathrm{~nm}$ ), see SI for details. 
Diethyl-4,6-di(pyren-1-yl)isophthalate (2)

Diethyl 4,6-dibromoisophthalate ${ }^{26}(0.50 \mathrm{~g}, 1.32 \mathrm{mmol})$, pyren-1-yl boronic acid $(0.71 \mathrm{~g}, 2.89 \mathrm{mmol}), \mathrm{K}_{2} \mathrm{CO}_{3}$ $(2.60 \mathrm{~g}, 9.07 \mathrm{mmol})$ and $\mathrm{Pd}\left(\mathrm{PPh}_{3}\right)_{4}(0.16 \mathrm{~g}, 0.14 \mathrm{mmol})$ were dissolved a degassed mixture of toluene/water (30 $\mathrm{mL} / 9.5 \mathrm{~mL}$ ). The mixture was warmed to $110^{\circ} \mathrm{C}$ and stirred overnight. After cooling to room temperature, saturated solution of chloride ammonium $(30 \mathrm{~mL})$ was added, and organic layer was extracted with dichloromethane $(4 \times 75 \mathrm{~mL})$. The combined organic extracts were dried over magnesium sulfate, filtered, and concentrated under reduced pressure. The residue was purified by flash chromatography on silica gel to afford a yellow-brown solid $(0.71 \mathrm{~g}, 86 \%)$. [column conditions: Silica cartridge $4 \mathrm{~g}$ (Serlabo); solid deposit on Celite ${ }^{\circledR} ; \lambda_{\text {detection }}$ : $(280 \mathrm{~nm}, 370$ $\mathrm{nm}) ; \mathrm{CH}_{2} \mathrm{CL}_{2}$ in light petroleum at $50 \mathrm{~mL} / \mathrm{min}(7 \mathrm{~min} / 10 \% ; 8 \mathrm{~min} / 10 \%->50 \%$; $14 \mathrm{~min} / 50 \%)$; collected fraction: $18-28 \mathrm{~min}$ ]. $\mathrm{mp}$ (light petroleum) $=103^{\circ} \mathrm{C}$. This molecule is not perfectly symmetric: there are two different signals for Me group in ${ }^{1} \mathrm{H}$ NMR and most of signals are doubled in ${ }^{13} \mathrm{C}$ NMR (38 signals detected for 44 signals expected). ${ }^{1} \mathrm{H}$ NMR $\left(300 \mathrm{MHz}, \mathrm{CD}_{2} \mathrm{Cl}_{2}\right) \delta 8.80(\mathrm{~s}, 1 \mathrm{H}), 8.28-8.16(\mathrm{~m}, 6 \mathrm{H}), 8.13-7.91(\mathrm{~m}, 12 \mathrm{H}), 7.74(\mathrm{~d}, J=2.7$ $\mathrm{Hz}, 1 \mathrm{H}), 3.96-3.77\left(\mathrm{~m}, 4 \mathrm{H}, \mathrm{CH}_{2}\right), 0.60(\mathrm{t}, J=7.1 \mathrm{~Hz}, 3 \mathrm{H}, \mathrm{Me}), 0.59(\mathrm{t}, J=7.1 \mathrm{~Hz}, 3 \mathrm{H}, \mathrm{Me}) .{ }^{13} \mathrm{C} \mathrm{NMR}(75 \mathrm{MHz}$, $\left.\mathrm{CD}_{2} \mathrm{Cl}_{2}\right) \delta 167.1(\mathrm{C}), 145.1(\mathrm{C}), 145.14(\mathrm{C}), 137.05(\mathrm{CH}), 136.9(\mathrm{CH}), 136.6(\mathrm{C}), 136.5(\mathrm{C}), 132.64(\mathrm{CH}), 132.59$ $(\mathrm{CH}), 132.24(\mathrm{C}), 132.23(\mathrm{C}), 131.97(\mathrm{C}), 131.96(\mathrm{C}), 131.40(\mathrm{C}), 131.39(\mathrm{C}), 129.3$ (C), $128.34(\mathrm{CH}), 128.31$ $(\mathrm{CH}), 128.1(\mathrm{CH}), 127.91(\mathrm{CH}), 127.91(\mathrm{CH}), 127.32(\mathrm{CH}), 127.29(\mathrm{CH}), 126.67(\mathrm{CH}), 126.66(\mathrm{CH}), 125.9$ $(\mathrm{CH}), 125.6(\mathrm{CH}), 125.19(\mathrm{CH}), 125.17(\mathrm{CH}), 125.16(\mathrm{C}), 125.15(\mathrm{C}), 124.94(\mathrm{C}), 124.91(\mathrm{C}), 124.87(\mathrm{CH})$, $124.8(\mathrm{CH}), 61.5\left(\mathrm{CH}_{2}\right), 13.71(\mathrm{Me}), 13.70(\mathrm{Me})$. HRMS $\left(\mathrm{ESI}^{+}, \mathrm{CH}_{2} \mathrm{Cl}_{2} /\right.$ acetone, $\left.95 / 5\right) \mathrm{m} / \mathrm{z}$ : $[\mathrm{M}+\mathrm{Na}]^{+}$calcd for $\mathrm{C}_{44} \mathrm{H}_{30} \mathrm{O}_{4} \mathrm{Na}$ 645.20363; Found 645.2035.

\section{7,7,9,9-tetraphenyl-7,9-dihydro-dinaphtho[2,1,8,7-defg:2',1',8',7'-Imno]heptacene (6)}

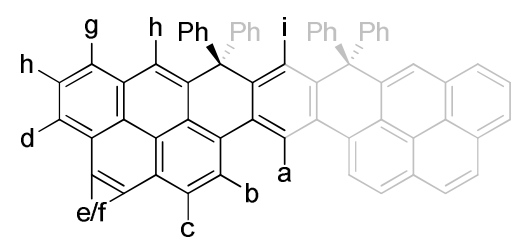

A phenyllithium solution $(2.6 \mathrm{~mL}, 4.62 \mathrm{mmol}) 1.8 \mathrm{M}$ in $\mathrm{Bu}_{2} \mathrm{O}$ was added dropwise to a solution of diester $2(0.48$ $\mathrm{g}, 0.77 \mathrm{mmol})$ dissolved in dry THF $(20 \mathrm{~mL})$ at $-10^{\circ} \mathrm{C}$. After $30 \mathrm{~min}$ at $-10^{\circ} \mathrm{C}$, the reaction was quenched by addition of methane sulfonic acid $(1.0 \mathrm{~mL}, 15.4 \mathrm{mmol})$ and the mixture stirred at $20^{\circ} \mathrm{C}$ for $30 \mathrm{~min}$. Then the mixture was quenched by addition of water $(20 \mathrm{~mL})$ and the organic layer was extracted with dichloromethane $(3 \times 100$ $\mathrm{mL}$ ). The combined organic extracts were dried over anhydrous magnesium sulfate, filtered, and concentrated under reduced pressure. The residue was then purified by flash chromatography on silica gel to afford a yellowbrown solid (0.68 g, 95\%). [column conditions: Silica cartridge $24 \mathrm{~g}$ (Serlabo); solid deposit on Celite ${ }^{\circledR}$; $\lambda_{\text {detection}}$ : $(280 \mathrm{~nm}, 370 \mathrm{~nm}) ; \mathrm{CH}_{2} \mathrm{Cl}_{2}$ in light petroleum at $50 \mathrm{~mL} / \mathrm{min}(15 \mathrm{~min} / 10 \%->50 \% ; 10 \mathrm{~min} / 50 \% ; 10 \mathrm{~min} / 50 \%$ $>100 \%$ ); collected fraction: $12-30 \mathrm{~min}] . \mathrm{mp}\left(\mathrm{CH}_{2} \mathrm{Cl}_{2}\right)>350^{\circ} \mathrm{C}$ (destruction). ${ }^{1} \mathrm{H}$ NMR $\left(300 \mathrm{MHz}, \mathrm{CD}_{2} \mathrm{Cl}_{2}\right) \delta 9.04$ (s, 1H, Ha), 8.88 (d, $J=8.5 \mathrm{~Hz}, 2 \mathrm{H}, \mathrm{Hb}), 8.35$ (d, $J=8.2 \mathrm{~Hz}, 2 \mathrm{H}, \mathrm{Hc}), 8.19$ (dd, $J=7.3,1.4 \mathrm{~Hz}, 2 \mathrm{H}, \mathrm{Hd}), 8.13$ (d, $J=9.0 \mathrm{~Hz}, 2 \mathrm{H}, \mathrm{He}), 8.09$ (d, $J=9.0 \mathrm{~Hz}, 2 \mathrm{H}, \mathrm{Hf}), 8.03(\mathrm{dd}, J=7.8,1.4 \mathrm{~Hz}, 2 \mathrm{H}, \mathrm{Hg}), 8.00-7.94(\mathrm{~m}, 2 \mathrm{H}, \mathrm{Hh})$, 7.75 (s, 2H, Hi), $7.18-7.08(\mathrm{~m}, 12 \mathrm{H}, \mathrm{Ph}), 7.06-6.98(\mathrm{~m}, 8 \mathrm{H}, \mathrm{Ph}), 6.84(\mathrm{~s}, 1 \mathrm{H}, \mathrm{Hj}) .{ }^{13} \mathrm{C} \mathrm{NMR}\left(75 \mathrm{MHz}, \mathrm{CD}_{2} \mathrm{Cl}_{2}\right)$ $\delta 147.4(\mathrm{C}), 142.1(\mathrm{C}), 141.0(\mathrm{C}), 135.7(\mathrm{CH}), 132.5(\mathrm{C}), 131.8(\mathrm{C}), 131.7(\mathrm{CH}), 131.3(\mathrm{C}), 130.6(\mathrm{CH}), 129.8$ $(\mathrm{CH}), 128.0(\mathrm{CH}), 127.9(\mathrm{C}), 127.8(\mathrm{CH}), 127.7(\mathrm{CH}), 126.8(\mathrm{CH}), 126.7(\mathrm{CH}), 126.2(\mathrm{CH}), 125.8(\mathrm{C}), 125.7$ $(\mathrm{CH}), 125.6(\mathrm{CH}), 124.9(\mathrm{C}), 124.1(\mathrm{C}), 120.9(\mathrm{CH}), 120.5(\mathrm{CH}), 60.6(\mathrm{C})$. HRMS (ESI $\left.{ }^{+}, \mathrm{CH}_{2} \mathrm{Cl}_{2}\right) \mathrm{m} / \mathrm{z}:[\mathrm{M}]^{+}$calcd for $\mathrm{C}_{64} \mathrm{H}_{38}$ 806.29680; Found 806.2964.

\section{ASSOCIATED CONTENT}

Supporting Information. Details on structural/thermal/electrochemical properties, theoretical modeling, device data, 2D NMR studies and copies of NMR spectra. The Supporting Information is available free of charge on the ACS Publications website. 


\section{AUTHOR INFORMATION \\ *Cyril.poriel@univ-rennes1.fr}

\section{AUTHOR CONTRIBUTIONS}

The manuscript was written through contributions of all authors. All authors have given approval to the final version

\section{ACKNOWLEDGMENT}

We thank the CDIFX and CRMPO (Rennes) and especially C. Orione, the ISN (Gif sur Yvette), The CINES (Montpellier, allocation 2017-A0020805032 awarded by GENCI), the Region Bretagne and the ADEME for a studentship (MR) and the ANR (n $14-C E 05-0024)$ for a post-doctoral position (CQ).

\section{REFERENCES}

(1) Marder, S. R.; Bredas, J.-L. The WSPC Reference on Organic Electronics: Organic Semiconductors, 2016.

(2) Chem. Phys. Chem. Special issue Organic Electronics 2015, 16, 1097-1314.

(3) Isr. J. Chem. Special Issue: Organic Electronics 2014, 54, 413-835.

(4) Figueira-Duarte, T. M.; Müllen, K. Chem. Rev. 2011, 111, 7260-7314.

(5) Xiao, J.; Duong, H. M.; Liu, Y.; Shi, W.; Ji, L.; Li, G.; Li, S.; Liu, X.-W.; Ma, J.; Wudl, F.; Zhang, Q. Angew. Chem. Int. Ed. 2012, 51, 6094-6098.

(6) Anthony, J. E. Chem. Rev. 2006, 106, 5028-5048.

(7) Anthony, J. E. Angew. Chem. Int. Ed. 2008, 47, 452-483.

(8) Lorbach, D.; Wagner, M.; Baumgarten, M.; Mullen, K. Chem. Commun. 2013, 49, 10578-10580.

(9) Saragi, T. P. I.; Spehr, T.; Siebert, A.; Fuhrmann-Lieker, T.; Salbeck, J. Chem. Rev. 2007, 107, 1011-1065.

(10) Wu, Y.; Zhang, J.; Bo, Z. Org. Lett. 2007, 9, 4435-4438.

(11) Poriel, C.; Rault-Berthelot, J. J. Mater. Chem. C 2017, 5, 3869-3897

(12) Wu, Y.; Zhang, J.; Fei, Z.; Bo, Z. J. Am. Chem. Soc. 2008, 130, 7192-7193.

(13) Romain, M.; Quinton, C.; Tondelier, D.; Geffroy, B.; Jeannin, O.; Rault-Berthelot, J.; Poriel, C. J. Mater. Chem. C 2016, 4, 16921703 .

(14) Romain, M.; Tondelier, D.; Jeannin, O.; Geffroy, B.; Rault-Berthelot, J.; Poriel, C. J. Mater. Chem. C 2015, 3, 9701-97014.

(15) Romain, M.; Tondelier, D.; Geffroy, B.; Jeannin, O.; Jacques, E.; Rault-Berthelot, J.; Poriel, C. Chem. Eur. J. 2015, 21, 9426-9439,

(16) Poriel, C.; Barrière, F.; Thirion, D.; Rault-Berthelot, J. Chem. Eur. J. 2009, 15, 13304-13307.

(17) Romain, M.; Tondelier, D.; Vanel, J.-C.; Geffroy, B.; Jeannin, O.; Rault-Berthelot, J.; Métivier, R.; Poriel, C. Angew. Chem. Int. Ed 2013, 52, 14147-14151.

(18) Rao, M. R.; Desmecht, A.; Perepichka, D. F. Chem. Eur. J. 2015, 21, 6193-6201.

(19) Wakim, S.; Leclerc, M. Synlett. 2005, 1223-1234.

(20) Blouin, N.; Michaud, A.; Wakim, S.; Boudreault, P.-L. T.; Leclerc, M.; Vercelli, B.; Zecchin, S.; Zotti, G. Macromol. Chem. Phvs. 2006, 207, 166-174.

(21) Wang, Z.; Li, R.; Chen, Y.; Tan, Y.-Z.; Tu, Z.; Gao, X. J.; Dong, H.; Yi, Y.; Zhang, Y.; Hu, W.; Mullen, K.; Chen, L. J. Mater. Chem. C 2017, 5, 1308-1312.

(22) Lee, J.; Park, J. Org. Lett. 2015, 17, 3960-3963.

(23) Wu, Z.-H.; Huang, Z.-T.; Guo, R.-X.; Sun, C.-L.; Chen, L.-C.; Sun, B.; Shi, Z.-F.; Shao, X.; Li, H.; Zhang, H.-L. Angew. Chem. Int. Ed. 2017, 56, 13031-13035.

(24) Kawano, S.-i.; Baumgarten, M.; Chercka, D.; Enkelmann, V.; Mullen, K. Chem. Commun. 2013, 49, 5058-5060.

(25) Reus, C.; Lechner, M. P.; Schulze, M.; Lungerich, D.; Diner, C.; Gruber, M.; Stryker, J. M.; Hampel, F.; Jux, N.; Tykwinski, R. R. Chem. Eur. J. 2016, 22, 9097-9101.

(26) Romain, M.; Chevrier, M.; Bebiche, S.; Mohammed-Brahim, T.; Rault-Berthelot, J.; Jacques, E.; Poriel, C. J. Mater. Chem. C 2015, 3, 5742-5753.

(27) Reed, C. A.; Fackler, N. L. P.; Kim, K.-C.; Stasko, D.; Evans, D. R.; Boyd, P. D. W.; Rickard, C. E. F. J. Am. Chem. Soc. 1999, 121, 6314-6315.

(28) Poriel, C.; Métivier, R.; Rault-Berthelot, J.; Thirion, D.; Barrière, F.; Jeannin, O. Chem. Commun. 2011, 47, 11703-11705.

(29) Valentine, A. J. S.; Mazziotti, D. A. J. Phys. Chem. A 2013, 117, 9746-9752.

(30) Cocherel, N.; Poriel, C.; Rault-Berthelot, J.; Barrière, F.; Audebrand, N.; Slawin, A. M. Z.; Vignau, L. Chem. Eur. J. 2008, 14, 11328-11342.

(31) Kulkarni, A. P.; Tonzola, C. J.; Babel, A.; Jenekhe, S. A. Chem. Mater. 2004, 16, 4556-4573.

(32) Takahashi, T.; Takenobu, T.; Takeya, J.; Iwasa, Y. Adv. Funct. Mater. 2007, 17, 1623-1628.

(33) Bachman, J. C.; Kavian, R.; Graham, D.; Kim, D. Y.; Noda, S.; Nocera, D. G.; Shao-Horn, Y.; Lee, S. W. Nat. Commun. 2015, 6, 1-9.

(34) Poriel, C.; Rault-Berthelot, J.; Thirion, D. J. Org. Chem. 2013, 73, 886-898.

(35) Clar, E. Chem. Ber. 1948, 81, 520-527.

(36) Sicard, L.; Quinton, C.; Peltier, J.-D.; Tondelier, D.; Geffroy, B.; Biapo, U.; Métivier, R.; Jeannin, O.; Rault-Berthelot, J.; Poriel, C. Chem. Eur. J. 2017, 23, 7719-7723.

(37) Altomare, A.; Burla, M. C.; Camalli, M.; Cascarano, G.; Giacovazzo, C.; Guagliardi, A.; Moliterni, A. G. G.; Polidori, G.; Spagna, R. J. Appl. Crvst. 1999, 32, 115-119. 
(38) Sheldrick, G. M. Acta Cryst. Sect. A 2008, A64, 112-122.

(39) Farrugia, L. J. Appl. Cryst. 1999, 32, 837-838.

(40) Cardona, C. M.; Li, W.; Kaifer, A. E.; Stockdale, D.; Bazan, G. C. Adv. Mater. 2011, 23, 2367-2371.

(41) Becke, A. D. Phys. Rev. 1988, 38, 3098-3100.

(42) Becke, A. D. J. Chem. Phys. 1993, 98, 1372-1377.

(43) Becke, A. D. J. Chem. Phys. 1993, 98, 5648-5652.

(44) Lee, C.; Yang, W.; Parr, R. G. Phys. Rev. B 1988, 37, 785-789.

(45) Frisch, M. J.; Trucks, G. W.; Schlegel, H. B.; Scuseria, G. E.; Robb, M. A.; Cheeseman, J. R.; Scalmani, R.; Barone, G.; Mennucci, B.; Petersson, G. A.; Nakatsuji, H.; Caricato, M.; Li, X.; Hratchian, H. P.; Izmaylov, A. F.; Bloino, J.; Zheng, G.; Sonnenberg, J. L.; Hada, M.; Ehara, M.; Toyota, K.; Fukuda, R.; Hasegawa, J.; Ishida, M.; Nakajima, T.; Honda, Y.; Kitao, O.; Nakai, H.; Vreven, T.; Montgomery, J. A. J.; Peralta, J. E.; Ogliaro, F.; Bearpark, M.; Heyd, J. J.; Brother, E.; Kudin, K. N.; Staroverov, V. N.; Kobayashi, R.; Normand, J.; Raghavachari, K.; Rendell, A.; Burant, J. C.; Iyengar, S. S.; Tomasi, J.; Cossi, M.; Rega, N.; Millam, N. J.; Klene, M.; Knox, J. E.; Pomelli, C.; Ochterski, J. W.; Martin, R. L.; Morokuma, K.; Zakrzewski, V. G.; Voth, G. A.; Salvador, P.; Dannenberg, J. J.; Dapprich, S.; Daniels, A. D.; Farkas, O.; Foresman, J. B.; Ortiz, J. V.; Cioslowski, J.; Fox, D. J. Gaussian 09, version A02, Gaussian, Inc., Wallingford, CT, 2009. 2009. 